\title{
EXPROPRIATION OF FOREIGN INVESTMENTS: AN OVERVIEW OF DISPUTABLE ISSUES THROUGH THE CASE LAW
}

\author{
ЕКСПРОПРІАЦІЯ ІНОЗЕМНИХ ІНВЕСТИЦЙ: \\ ОГЛЯД СПІРНИХ ПИТАНЬ ЧЕРЕЗ СУДОВУ ПРАКТИКУ
}

\author{
Kucheruk K.I., Student of the Faculty of Economics and Law \\ Yaroslav Mudryi National Law University
}

The protection of foreign investments is one of the key issue for those who invest outside their own jurisdiction. One of the major developed and proliferating area of legal practice is the protection of foreign investments by means of treaties entered into between countries and designed to guarantee protection for investors' assets. Bilateral investment treaties widely use provisions about expropriation, which is one of the most emotive issue in the international investment law as it ultimately affects the investors' investments and could essentially extinguish the rights that investors have in respect to their property. Expropriation in a broad sense is a state's entitlement under the international law to deprive someone's assets and an obligation to pay compensation for the act of expropriation. As practice shows, in particular, International Centre for Settlement of Investment Disputes practice, the majority of investment disputes between foreign investors and host countries comes down to the question whether the expropriation was lawfully carried out and whether compensation was paid. Among reason of the prevalence of cases in regard expropriation of foreign investments is the absence of one international act that would enshrine the concept of indirect expropriation and similar measures, therefore the situational case-by-case approach is the only way to develop more or less well-established list of actions that belongs to this category.

In the article, the author scrutinize the very nature of the expropriation, draw a parallel between expropriation de facto and means of indirect expropriation, compare expropriation with legal state's regulatory policy through the prism of decisions of international tribunals.

Key words: investments, expropriation, assets, regulatory policy, ICSID, compensation.

Захист міжнародних інвестицій є актуальним та вагомим питанням для інвесторів, що обирають шлях закордонного інвестування. Найпоширенішим юридичним інструментом захисту інвестицій визнається укладання двосторонніх інвестиційних договорів, що покликані нівелювати можливі ризики та гарантувати недоторканість іноземних активів. У більшості двосторонніх інвестиційних договорів містяться положення щодо експропріації іноземних інвестицій, що залишається одним з найбільш неоднозначних та складних питань міжнародного інвестиційного права через значний вплив на реалізацію інвестором прав власності. Експропріація у широкому значенні $€$ прикладом прояву державного суверенітету і полягає у праві заволодіння чужими активами та обов'язку компенсувати колишньому власнику її вартість. Незважаючи на те, що міжнародні правові акти передбачають можливість експропріації, більшість справ між міжнародними інвесторами та приймаючими державами, що були розглянуті або перебувають у віданні арбітражів, стосуються правомірності експропріації та її компенсації. Серед причин виникнення великої кількості суперечностей доцільно виділити відсутність єдиного міжнародного акта, який би конкретизував види експропріації та перелічив їх ознаки, адже на такому етапі розвитку міжнародного інвестиційного права уніфікація термінів відбувається лише завдяки сумлінній праці арбітражів, які, однак, не завжди є послідовними у своїх висновках. Крім того, не всі дії держави, які націлені на обмеження або позбавлення права власності іноземного інвестора, є експропріацією. Насамперед йдеться про заходи, пов'язані з регуляторною політикою держави та публічним інтересом, а саме оподаткуванням, ліцензуванням, обмеженням зовнішньої торгівлі, валютним регулюванням, експортним контролем, антимонопольним законодавством, захистом навколишнього середовища, захистом прав споживачів, регулюванням цінних паперів тощо.

У статті авторка досліджує природу експропріації, окреслює її види, виокремлює певні невирішені питання щодо компенсації, порівнює експропріацію та державні регуляторні засоби крізь призму висновків міжнародних інвестиційних трибуналів.

Ключові слова: інвестиції, право власності, експропріація, компенсація, арбітраж.

Expropriation of investments is determined to be a thorny issue in the domain of international investment law. From one side, it could be regarded as a significant intervention into the enjoyment of investor's property rights, and from other side, the explicit expression of state's sovereignty power. In the absence of efficient normative regulation and sufficient specialized glossary, as well as numerous bilateral investment treaties and inconsistent practice of dispute resolution institutions, considering the importance of the topic for the current investors and creation the most pleasant microclimate for the investments of the potential ones, the notion of the expropriation of investor's assets deserves the rigorous scrutiny both by governmental agencies and private actors.

The common misconception leads to the understanding expropriation as illegal acquisition of individual's property. The same meaning can be found in the Cambridge dictionary which states that expropriation is the act of taking away money or property, especially for public use without payment to the owner, or for personal use illegally. Ukrainian legislation hasn't got the term expropriation at all, in spite of its usage in the several legal acts, for instance, the Law On Sanctions No 1644-VII from 14.08.2014 [1]. Moreover, the confusion is arisen when such phenomenon as nationalization, confiscation and expropriation should be distinguished. Notwithstanding the failing of universally accepted meaning, in most cases these terms are interchangeable, their use typically depends on legal tradition and translation [2]. Another approach is defining expropriation as a generic concept, which includes both nationalization and confiscation and the difference depends on the scale of activity: from this point of view, nationalization is a large-scale process, which may include gaining state control over the private enterprises in the industry and creating a state monopoly [3].

In the field of international investment law, the term "expropriation" is often used, international agreements and bilateral investment treaties include it, but despite the common acknowledge of unified expropriation peculiarities, there is no one generally recognized term. Expropriation and similar measures - any legislative action or administrative action or omission attributable to the host government which has the effect of depriving the holder of a guarantee of his ownership or control of, or a substantial benefit from, his investment, with the exception of nondiscriminatory measures of general application which governments normally take for the purpose of regulating economic activity in their territories [4]. This definition names and emphasizes important aspects in regard expropriation, due to which the contradictions are flourishing: what are similar measure to expropriation, what scale of the impact on rights should take place to be considered as expropriation, what are exceptions that could be scrutinized as regulation of states economy. North American free trade agreement and the energy charter treaty precise the above-mentioned term, the former distinguish direct and indirect expropriation [5], and noteworthy that both of them generally prohibit any kind of expropriation except situations, when conditions match the listed mandatory 
features: public interest; non-discriminatory nature; compliance with the legal procedure; compensation [6]. The BITs contain the same reservations, for instance, investments shall not be expropriated or nationalized either directly or indirectly through measures tantamount to expropriation or nationalization ("expropriation") except: for public purpose; in a non-discriminatory manner; upon payment of prompt, adequate and effective compensation; and in accordance with due process of law and the general principles of treatment [7].

Consideration of the institution of expropriation solely in the context of transfer of the title to the property or its outright physical seizure does not correspond to regulatory legal acts in the field of international investment law, neither to judicial practice, nor to doctrine. The concept "expropriation" is much broader than any definition that operates only in terms of depriving a title to property. For instance, indirect expropriation involves total or near-total deprivation of an investment but without a formal transfer of title or outright seizure [2]. One of the most vivid implementation of indirect expropriation can be found in the case Metalclad v. Mexico where International Centre for Settlement of Investment Disputes stated "that expropriation under NAFTA $<\ldots>$ also covert or incidental interference with the use of property which has the effect of depriving the owner, in whole or in significant part, of the use or reasonably-to-be-expected economic benefit of property even if not necessarily to the obvious benefit of the host State" [8]. Additionally, such terms as "equivalent to expropriation" and "tantamount to expropriation" included in the international treaties do not have a clear or unequivocal definition, both expropriation methods may take place by their means of a broad number of actions that have to be examined on a case-by case basis to conclude if one of such expropriation methods has taken place [9].

One prominent aspect of questions of expropriation is the role, if any, that the purpose and circumstances of a particular governmental action can play in the legal assessment of whether expropriation has occurred. This serves as the count point to consider expropriation and similar measures as a lawful act and separate from illicit expropriation and also state's regulatory measures. The distinctions in such satiations are vital because in case of implementing regulatory measures state is not obliged to pay compensation to the investor whose assets were affected. In a broad sense unlawful expropriation is its execution without compliance with the mandatory requirements. Along with the definition of the concept of expropriation, taking into account possibility of execution unlawful expropriation, one the most important issue of the institution of expropriation in international investment law is the concept of compensation and the procedure for determining it. All sources of international investment law allow the expropriation of property of a foreign investor, but establish the requirement of compulsory compensation, which should follow after the expropriation. So expropriation without the compensation stands for the most frequent reason of recognition it illicit. For instance, while an expropriation or taking for environmental reasons may be classified as a taking for a public purpose, and thus may be legitimate, the fact that the property was taken for this reason does not alter the legal character of the taking for which adequate compensation must be paid [10]. The evaluation of the compensation is also the crux of the matter. In the doctrine of international investment law, two general principles of law are usually used to justify full compensation: the theory of inadmissibility of unjust enrichment and the theory of acquired rights [11]. The first one refers to the Rome maxima "Iure naturae aequum est neminem cum detrimento alterius et iniuria fieri locupletiorem" ("By natural law it is just that no one should be enriched by another loss or injury") and the expanded interpretation of the latter implies the preservation of rights not only as a result of changes in sovereignty over a certain territory, but also due to other changes affecting the rule of law. The second aspect, which is of fundamental importance in deciding the issue of the amount of compensation, is the choice of the method of investment assessment. Basically, principle of fair market pricing and "tantum bona valent, quantum vendi possunt" ("Goods are worth only so much as they can be sold for") is used. For instance, price indicated by the offer to acquire its share [12], value transaction of the previous transaction or the average price for this kind of assets in the particular market. Undoubtedly, the method differs from case to case and estimation may become a slippery slope: the question, for example, arises of assessing the value of enterprises that were not profitable in the course of their activities and even, conversely, were unprofitable.

Not all actions of the state that are aimed at restricting or depriving investors' rights to property are expropriation. First of all, measures related to taxation, licensing, restriction of foreign trade, currency regulation, export controls, antitrust laws can be determined as regulatory policy. Case Marvin Feldman v. Mexico concerns the tax rebates which may be available when cigarettes are exported. Tribunal stated that albeit due to changes of tax policy foreign investor was no longer able to engage in his business of purchasing Mexican cigarettes and exporting them, and has thus been deprived completely and permanently of any potential economic benefits from that particular activity, regulatory action was balanced and did not constitute expropriation [13]. On the other hand, in the case Tecnicas Medioambientales Teemed, S.A. v. the United Mexican States notwithstanding the connection with the licensing which is regarded as states regulatory police, tribunal alleged that expropriation took place. The claimant was the awardee of the public auction, got in his possession property and latter renewable license to landfill operation. As a result of the liquidation of some state bodies and the emergence of others, the management of the issuance of licenses passed to the environmental institute, which subsequently prohibited the issuance of a re-license. The argument of the state was that "denial of the permit is a control measure in a highly regulated sector and which is very closely linked to public interests". Nevertheless, tribunal proclaimed that due to the actions of the state, the assets involved have lost their value or economic use for their holder and the extent of the loss [14].

In general, two "tests" have been developed in arbitration practice that are used to settle whether certain government measures can be recognized as equivalent to expropriation. The first of these is to evaluate the investor's real control over investments and not the actual losses that he incurred or may incur in connection with such an intervention (as it was in the case Marvin Feldman v. Mexico). On the other hand, in arbitration practice there is another approach: in order to recognize the degree of interference with property rights, sufficient to establish the fact of expropriation, the arbitration tribunals need to evaluate not the owner's control over the investments, but the possibility of receiving income from them. In accordance with this approach, expropriation can be considered as actions that destroy or reduce the economic return on investment, regardless of actual control. In the case Tecnicas Medioambientales Teemed, S.A. v. the United Mexican States, unlike in the first situation, where the claimant reserved his right toward his investments albeit struggled some hardship, the prohibition of activity proves the forfeiture of investments.

To summarize, the modernunderstanding of "expropriation" in international investment law covers two types - direct expropriation, consisting in the adoption by the state of measures aimed at depriving a foreign investor of the right of ownership of the investment and indirect expropriation - total or near-total deprivation of an investment but without a formal transfer of title or outright seizure. The second type applies to measures equivalent to expropriation, which are understood as measures of public-power influence, whose influence on the investor's ownership deprives the investor of the actual 
opportunity to profit from their investments and violate the reasonable legitimate expectations. Whether direct or indirect expropriation took place, state is obliged to reimburse the lost value of the property, which is leading us to the concept of fair compensation and different approaches of its estimation.

Considering all aforementioned points it should be noted that despite rare consolidation in model bilateral investment treaties the directly listed criteria of indirect expropriation, the fixation of features of state's regulatory measures hasn't yet became a rule. In order to avoid violation of investors' rights and create uniformity in the interpretation and application by arbitration of the standards of expropriation in the provisions of international treaties, it is necessary to clearly stipulate what actions of the state cannot be recognized as expropriation and entail, accordingly, the payment of compensation to the investor.

\section{REFERENCES}

1. Закон України «Про санкції». Відомості Верховної Ради (BBP), 2014, № 40, ст. 2018. Із змінами, внесеними згідно із Законом № 2195-VIII від 09.11.2017, ВBP, 2018, № 1, ст. 2, ст. 3. URL: https://zakon.rada.gov.ua/laws/show/1644-18 (Last accessed: 26.03.2020).

2. Expropriation. UNCTAD Series on Issues in International InvestmentAgreements II. URL: https://unctad.org/en/Docs/unctaddiaeia2011d7_ en.pdf (Last accessed: 26.03.2020).

3. Commeaux P.E., Kinsella S.N. Protecting Foreign Investment Under International Law, Legal Aspects of Political Risk. New York : Oceana Publishing, 1997

4. The Convention Establishing the Multilateral Investment Guarantee Agency (MIGA). URL https://www.miga.org/sites/default/files/archive/ Documents/MIGA\%20Convention\%20(April\%202018).pdf (Last accessed: 26.03.2020).

5. North American Free Trade Agreement. URL: https://idatd.cepal.org/Normativas/TLCAN/Ingles/North_American_Free_Trade_ Agreement-NAFTA.pdf (Last accessed: 26.03.2020).

6. The energy charter treaty (with incorporated trade amendment) and Related Documents. URL: https://www.europarl.europa.eu/ meetdocs/2014_2019/documents/itre/dv/energy_charter_/energy_charter_en.pdf (Last accessed: 26.03.2020).

7. Treaty between the United States of America and Ukraine concerning the encouragement and reciprocal protection of investment, with annex, and related exchange of letters, done at Washington on March, 4 1994. URL: https://tcc.export.gov/Trade_Agreements/All_Trade_ Agreements/exp 005484.asp (Last accessed: 26.03.2020).

8. Metalclad v. Mexico CASE No. ARB(AF)/97/1. URL: https://www.italaw.com/sites/default/files/case-documents/ita0510.pdf (Last accessed: 27.03 .2020 ).

9. Técnicas Medioambientales Tecmed, S.A. v. the United Mexican States, ICSID Case No. ARB (AF)/00/2. URL: https://www.italaw.com/ sites/default/files/case-documents/ita0854.pdf (Last accessed: 27.03.2020).

10. Compañía del Desarrollo de Santa Elena S.A. v. the Republic of Costa Rica Case No. ARB/96/1. URL: https://www.italaw.com/sites/ default/files/case-documents/italaw6340.pdf (Last accessed: 27.03.2020).

11. The International Law on Foreign Investment. M. Sornarajahl. Cambridge University Press; 3 edition. June 14, 2010.

12. CME Czech Republic B.V. v. the Czech Republic. URL: https://www.italaw.com/sites/default/files/case-documents/ita0180.pdf (Last accessed: 27.03 .2020 ).

13. Marvin Feldman v. Mexico No. ARB(AF)/99/1. URL: https://www.italaw.com/sites/default/files/case-documents/ita0319.pdf (Last accessed: 27.03 .2020$)$.

14. Tecnicas Medioambientales Teemed, S.A. v. the United Mexican States No. ARB (AF)/00/2. URL: https://www.italaw.com/sites/default/ files/case-documents/ita0854.pdf (Last accessed: 28.03.2020). 